\title{
ADAPTIVE THERMAL COMFORT IN THE WET TROPICS FOR HOUSING DESIGN WITH PASSIVE COOLING
}

\author{
Djamila Harimi ${ }^{1}$, Narayanan Sambu Potty ${ }^{2}$, Chi Chu Ming ${ }^{3}$ \\ ${ }^{1}$ Research Scholar, School of Engineering and Information Technology, Universiti Malaysia Sabah, Malaysia \\ ${ }^{2}$ Civil Engineering Department, Universiti Technologi, Malaysia. \\ ${ }^{3}$ Chemical Program, Universiti Malaysia Sabah, Malaysia. \\ Email : 'harimi1@yahoo.fr
}

\begin{abstract}
Current developments in adaptive concept in thermal comfort research have underlined the importance of exploring thermal comfort in different environmental contexts. A better understanding in this area becomes a challenging topic to explore for development of suitable comfort standard for the wet tropics for thermal housing design with passive cooling. This study uses the adaptive thermal comfort model with different approaches to assess the applicability of these approaches in the wet tropics. The neutral temperature for regions having wet tropical climate including Kota Kinabalu, the capital of Sabah State located in east Malaysia was estimated and a comparison between different approaches was made. The limitation of the adaptive approach in the humid tropics was further clarified. The required air movement for thermal comfort for the wet tropics was also suggested.
\end{abstract}

Key words: Thermal Comfort; Adaptive Approach; Neutral temperature; Wet tropics.

\section{INTRODUCTION}

Worldwide, buildings consume approximately $40 \%$ of the used overall energy flows. Heating, cooling and ventilation requirements of a conventional building represent more than $50 \%$ of its overall energy consumption [1]. In the early twentieth century, people have entered into researching on thermal comfort to predict people's comfortable sense [2]. ISO 7730 [3] and ASHRAE 55-1992 standards [4] for comfort zones are well known and widely used all over the world despite their limitations. These standards are based on research conducted by Fanger's [5] at Kansas State University and at other institutions for summer and winter at steady state heat transfer theory under climate chamber. The time factor in Fanger's formula is not considered, whereas the occupants will respond to change in the environment by adjustments in clothing and activity levels [6], [7]. Further the body temperature also varies over the course of a day [21] and reaches its minimum at about 5:00a.m. While we accept these cycles as normal in nature, we ignore such fact in building design by constructing air-conditioned modern building with a fixed temperature rather than adapting passive designs which allows indoor temperature variation but improve the indoor thermal conditions

Researchers of thermal comfort field studies have suggested that people are not passive receivers of their thermal environment. They adjust or acclimatize to their environment (8). Acclimatization is a factor to be included in human response to comfort. Humphreys and Nicol [9], Nicol [7], Wong and Khoo [10] and Feriadi and Wong [11] showed that people living in warmer regions prefer hotter temperature than that given by Fanger and prescribed in ASHRAE standard 55 [4] and ISO 7730 [3]. ASHRAE Comfort zone is not simply considered inappropriate for predicting indoor thermal comfort under tropical humid condition but rather for an air-conditioned space. The adoption of ISO comfort zone under Malaysian climate and wet tropics countries could also increase their cooling bills for maintaining the required indoor temperature. The adaptive comfort models shows that people could greatly ameliorate the indoor comfort by controlling their local environment in naturally ventilated buildings, such as changing their clothing or their activities, opening windows or switching on a fan [7]. The effect of adaptive behaviors on optimum comfort temperature was more detailed by Oseland [12]. ASHRAE Standard 55-2004 has recognized the importance of the adaptive approach and [4] includes an adaptive comfort standard for occupant-controlled naturally conditioned spaces.

\section{LITERATURE REVIEW OF DIFFERENT ADAPTIVES MODELS}

A review of selected studies of adaptive thermal comfort that can be applicable in the wet tropics is given below.

\section{Humphreys Model}

Based on studies from various countries around the world, Humphreys noticed a strong statistical dependence of thermal neutralities (Tn) on the mean levels of air or globe temperature (Ti) recorded inside the0buildings [13]. The temperature in which the thermal environment perceived by people neither considered cool nor warns is termed neutral temperature. Humphreys observed that 
the globe temperature can better indicate thermal comfort, rather than a multi-variable index and attributed this to the adaptive processes. The globe temperature is usually measured with globe thermometer, which enables to measure the effects of radiant heat from environmental conditions. Humphreys [14] suggested the following correlation to determine the neutral temperature based on indoor globe temperature $(\mathrm{OC})$. The $(r)$ is the regression coefficient estimated from the study

$$
\mathrm{Tn}=2.56+0.83 \mathrm{Ti}(\mathrm{r}=0.96)
$$

Humphreys [15] examined people's adaptation to the outdoor climate and presented a new neutral temperature formula for naturally ventilated building with air movement assumed to be equal or less than $0.1 \mathrm{~m} / \mathrm{s}$. The correlation was based on the mean monthly outdoor temperature $(0 \mathrm{C})$ as given below

$$
\mathrm{Tn}=0.534 \mathrm{Tm}+11.9 \AA=+0.97)
$$

Where

$\mathrm{Tm}$ is the mean monthly outdoor temperature

$\mathrm{Tn}$ is the comfort temperature

\section{Auliciems Model}

Auliciems [16] tried to reanalyse Humphrey's data by removing some irrelevant thermal comfort records such those using children as subjects and those with monthly outdoor temperatures below $-5^{\circ}$ and included the results of more recent field studies by combining data for buildings with active and passive climate control from various climatic zones. The suggested neutral comfort temperature $(\mathrm{Tn})$ was estimated from the mean indoor air temperature (Ti) and the mean monthly outdoor temperature $(\mathrm{Tm})$, through the following equation.

$$
\mathrm{Tn}=0.48 \mathrm{Ti}+0.14 \mathrm{Tm}+9.22(\mathrm{r}=0.95)
$$

For light weight building material or for highly ventilated building with opened windows, the indoor temperature can be assumed the same as outdoor temperature. The Auliciems models therefore become:

$$
\mathrm{Tn}=0.62 \mathrm{Tm}+9.22
$$

Barger and De Dear [13] reported that although the regression coefficients of Auliciems formula may be unstable due to intercorrelation between the two independent variables, The above equation (3) represents a widely cited statistical expression for the adaptive hypothesis of human thermal perception.

\section{De Dear and Brager Model}

A new evaluation model specified for thermalcomfort in naturally ventilated buildings named Adapted
Comfort Standard (ACS) was proposed by De Dear \& Brager [17] and included as the adaptive comfort standard in the revision of ASHRAE 55 Standards.[4] The raw data of their studies were collected from several locations in England and Wales, Bangkok Thailand, several Californian locations, Montreal and Ottawa in Canada, six cities across Australia, five cities in Pakistan, Athens in Greece, Indonesia, Singapore, and Grand Rapids in Michigan, nearly 22,000 raw data. De Dear \& Brager [17] derived the following comfort temperature equation based on mean outdoor temperature:

$$
\text { Tcomf }=0.31 \text { TA.OUT }+17.8
$$

Where TA.OUT is the monthly mean of the outdoor air temperature It was reported that the above adaptive comfort standard for naturally conditioned spaces is only applicable when windows can be readily opened to outdoor and adjusted by the occupants. Beside, occupants must be engaged in near sedentary activity (1-1.3 met) and must be able to freely adapt their clothing. This model can be applied when the mean monthly air temperature (Tmonth) is between 10 and $33^{\circ} \mathrm{C}$ [17]

\section{METHODOLOGY}

The aim of this study is to analyze the adaptive thermal comfort model with different approaches under wet tropical conditions. The first analysis was conducted for outdoor temperatures between 10 and $35^{\circ} \mathrm{C}$ where the De Dear and Brager adaptive model is considered applicable. A comparison between Humphreys, Auliciems and the De Dear- Brager adaptive models was made. The neutral temperature was estimated under wet tropical climate as well as in Kota Kinabalu the capital of sabah state located in east Malaysia, the required air movement for thermal comfort for the wet tropics was also suggested.

\section{ASSESSMENT OF THERMAL COMFORT WITH ADAPTIVE APPROACH}

The wet tropical climate is characterized by a relatively uniform temperature, high humidity, and high amount of cloud cover with intense solar radiation. The average annual air temperatures in this climate are about 25 to 27 OC [18]. The difference between the highest monthly mean air temperature and the lowest monthly mean air temperature is less or about $30 \mathrm{C}$. Common daily temperature maxima are 29 to $340 \mathrm{C}$, with daily minima of 20 to $240 \mathrm{C}$. The diurnal temperature range is about 6 to $40 \mathrm{C}$ which is greater than the annual [18]. The estimation of neutral temperature with adaptive formula under such climatic conditions might be more required for daily hourly variation instead of annual monthly variation. This is because the annual temperature range is smaller than the daily range and providing the basis for a saying generally 
quoted by climatologists "Night is the winter of the tropics" [18]. The average of 35 years monthly mean temperature (1968-2003) in Kota Kinabalu is given in Table 1 and the average hourly temperatures variation for the same location are plotted in Fig. 1. The data were recorded at Sabah Meteorological Station and at Kuala Lumpur Meteorological Station and the location is considered as a typical wet tropical climate.

Table 1. Monthly Mean Outdoor Temperature (1968-2003)

\begin{tabular}{|c|c|}
\hline Month & Temperature $\left({ }^{0} \mathbf{C}\right.$ ) \\
\hline January & 26.65 \\
\hline February & 26.85 \\
\hline March & 27.45 \\
\hline April & 28.15 \\
\hline May & 28.25 \\
\hline Jun & 27.9 \\
\hline July & 27.6 \\
\hline August & 27.6 \\
\hline September & 27.55 \\
\hline October & 27.35 \\
\hline November & 27.25 \\
\hline December & 27.25 \\
\hline Average & 27.48 \\
\hline
\end{tabular}

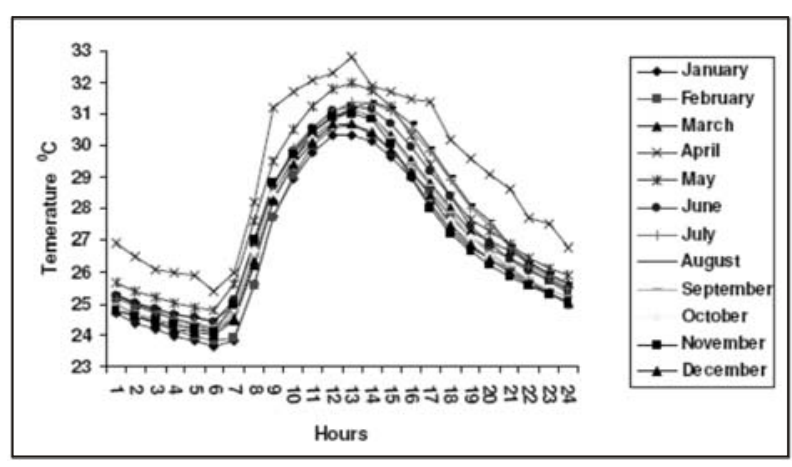

Fig. 1. Average hourly Temperature Variation (2001-2006)

From Table 1 and Fig. 1 , it can be concluded that the monthly temperature variation is lower than the hourly temperature variation. Therefore, the neutral temperature in the humid tropic may vary within 24 hours. Further research and surveys are needed to clarify the effect of hourly temperature variation on neutral comfort temperature.

The Equations (2), (4) \& (5) were used to analyze a wide range of outdoor temperatures of 10 to $35^{\circ} \mathrm{C}$. The mean outdoor temperatures for the wet tropics including Malaysia are about 25 to 27 or $280 \mathrm{C}$. The results obtained from Equations (2) and (5) are plotted in Fig. 2.

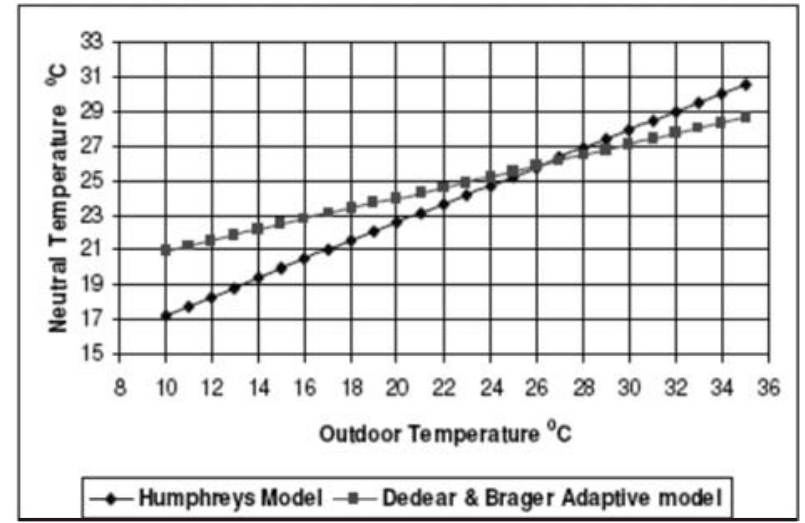

Fig. 2. Comfort Neutral Temperature

Table 2 summarizes the estimated neutral temperature for a typical wet climate including Malaysia using equations (2), (4) and (5).

\section{Table 2. Neutral Temperature $(\mathrm{OC})$ for Wet Tropical Climate}

\begin{tabular}{|c|c|c|c|}
\hline Tout & $\begin{array}{l}\text { Humphreys } \\
\text { Model }\end{array}$ & $\begin{array}{l}\text { De Dear \& } \\
\text { Brager Model }\end{array}$ & $\begin{array}{l}\text { Auliciems } \\
\text { Model }\end{array}$ \\
\hline 25 & 25.3 & 25.5 & 24.7 \\
\hline 26 & 25.8 & 25.9 & 25.3 \\
\hline 27 & 26.3 & 26.2 & 26 \\
\hline 28 & 26.8 & 26.6 & 26.5 \\
\hline Average & 26.1 & 26.1 & 25.6 \\
\hline
\end{tabular}

From the data analyzed above, it was noticed that the maximum difference in neutral temperature using equations (2) and (5) could reach up 3.7 $0 \mathrm{C}$ when outdoor temperature equal $100 \mathrm{C}$. The predicted neutral temperature using Humphreys and De Dear- Brager models are almost similar for a typical wet tropical climate with outdoor mean temperature of 25 to $280 \mathrm{C}$ as can be seen in Table 2. The Neutral temperature using Auliciems model was estimated with the assumption that indoor temperature is closer to outdoor temperature. This is very acceptable for highly ventilated building with opened windows or for building with low thermal mass. The Auliciems neutral temperartue is slightly lower than the Humphreys and De Dear-Brager Model by about 0.50C, which means the Auliciems model predict $0.50 \mathrm{C}$ indoor neutral temperature lower than Humphreys and De DearBrager models under wet tropical climate. The suggested neutral temperature for the wet tropic is about $260 \mathrm{C}$. It is necessary to mention that the average monthly temperature in Kota Kinabalu is slightly higher than the average temperature in the wet tropics. This is mainly due to the increase of outdoor temperature over decades; part of it is due to the $\mathrm{CO} 2$ from the combustion of fossil fuels for electric production. This could affect slightly the estimated 
neutral temperature. The increase of outdoor temperature could be the case of several countries located in the wet tropics in Southeast Asia undergoing rapid economic development at the present time [22].

\section{EFFECT OF AIR MOVEMENT ON INDOOR THERMAL COMFORT}

Air movement can be a most effective way for decreasing body temperature in warm-humid climates [23]. Air Velocity accelerates the rate of convective and evaporative heat loss from the human skin to the environment. Therefore, one feels cooler with a higher air velocity. The air movement required to achieve a cooling effect can be estimated with several formulas such as Aynsley and Gulson [24], Progres [25] and Humphreys [26]. Humphreys suggested the following for estimation of the cooling effect of the increased air velocity.

$$
\mathrm{CE}=7-50 /(4+10 \mathrm{~V} 0.5)
$$

Where, CE is the cooling effect, which allows air temperature to arise comfort temperature by $\mathrm{CE}(\mathrm{OC}), \mathrm{V}$ is air velocity $(\mathrm{m} / \mathrm{s})$.

The cooling effect for air movement of 0 to $5 \mathrm{~m} / \mathrm{s}$ were estimated with different methods and plotted in Fig. 3 .

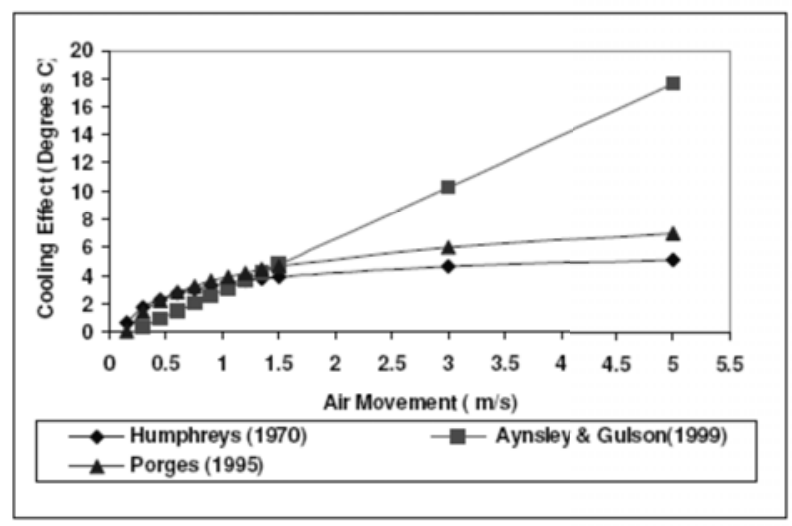

Fig. 3. Impact of Air Movement on Cooling Effect

As can be seen from Fig. 3, the divergence between results is significant when the air movement is greater than $1.5 \mathrm{~m} / \mathrm{s}$. Usually, the air velocity inside the building is less than $1 \mathrm{~m} / \mathrm{s}$. The required mean air velocity for thermal comfort as recommended by ISO 7730 should be less than $0.25 \mathrm{~m} / \mathrm{s}$ for sedentary activity during summer [3], whereas the recommended indoor air velocity according to Olgyay as reported by Tinker should be between 0.15 $\mathrm{m} / \mathrm{s}$ to $1.5 \mathrm{~m} / \mathrm{s}$ [27]. This is in agreement with several published studies under warmer environment as quoted from [19]. At the higher temperature range at air temperature around $300 \mathrm{C}$, the air velocities of about 1.6 $\mathrm{m} / \mathrm{s}$ have been found to be acceptable [20]. Therefore all the above formula has the same accuracy for air movement of about $1.5 \mathrm{~m} / \mathrm{s}$. Air movement of about $1.5 \mathrm{~m} / \mathrm{s}$ could be recommended for the humid tropic. This can be perfectly ensured by using a fan.

\section{THERMAL EVALUATION}

The estimated comfort temperature for the wet tropics was about $260 \mathrm{C}$. Air movement of about $1 \mathrm{~m} / \mathrm{s}$ can off set the excess temperature by $3.40 \mathrm{C}$. Therefore the upper recommended limit of comfort temperature with air movement of $1.5 \mathrm{~m} / \mathrm{s}$ is about $29.40 \mathrm{C}$. Plotting the upper limit of the comfort temperature on hourly outdoor temperature of Kota Kinabalu city as shown in Fig. 4, shows that thermal comfort will not be ensured from 10am to $16 \mathrm{pm}$. This could be the case of any building realized with low thermal mass or for any highly ventilated building with windows opened during daytime.

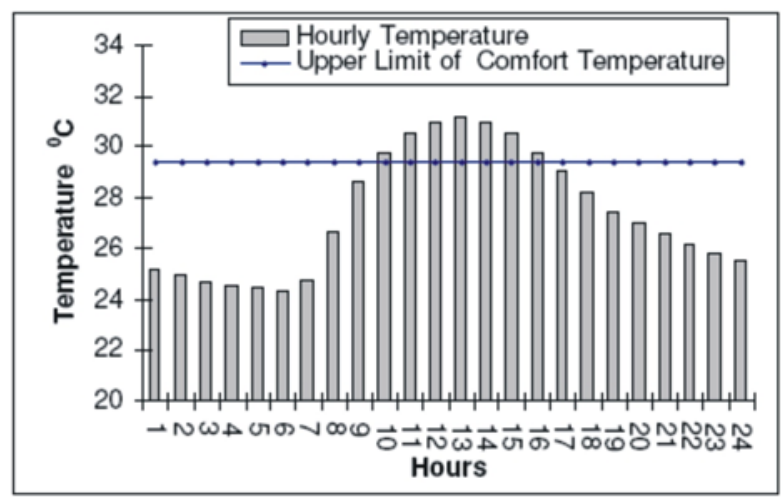

Fig. 4. Thermal comfort upper limits versus hourly outdoor temperature

\section{CONCLUSION}

The suggested neutral temperature for the wet tropics (with at least 10 months wet) conditions is about 26 OC all year round. This neutral temperature is applicable almost in any region at lower elevations. The use of Humphreys and De dear \& Brager thermal comfort approach models under wet tropical conditions gave nearly the same neutral temperature. This is not the case with Auliciems model. The predictive neutral temperature with adaptive approach under wet tropical climatic conditions might be more needed for hourly temperature variation instead of monthly variation, further investigation is recommended. The impact of air movement in this paper on cooling effect was clarified.

\section{ACKNOWLEDGEMENT}

The author acknowledges the help of the Associate Professor Dr Idris Zakaria. We acknowledge the help of Sabah and Kuala Lumpur Meteorological Station for the important climatic data. 


\section{REFERENCES}

[1] M Vladimir, 2005, Secrets to Climate Adapted Building Design, Conference World Sustainable Building Design, Tokyo, Japan

[2] Y Xie, 2005, The Evaluation of Indoor Thermal Comfort Index. Conference World Sustainable Building Design, Tokyo, Japan

[3] ISO 7730, 1995, Moderate Thermal Environment-Determination of the PMV and PPD Indices and Specifications for Thermal Comfort, Geneva, Switzerland: International Organization for Standardization

[4] ASHRAE Standard 55. 1992, Thermal Environmental Conditions for Human Occupancy, Atlanta, USA: Refrigerating and AirConditioning Engineers

[5] P O Fanger, 1970, Thermal comfort. Danish Technical Press, Copenhagen

[6] F Nicol, M AHumphreys, 2002, Adaptive Thermal Comfort and Sustainable Thermal Standards for Building, Energy and Building Journal, 34,563-572.

[7] F Nicol, 2004, Adaptive thermal Comfort Standards in the Hot-Humid Tropics. Energy and Building Journal, 36, 628-637.

[8] H Shahin, S Steve, 2001, A comparative Analysis of Short-Term and long-Term Thermal Comfort Surveys in Iran, Windsor, Windsor Conference, Windsor, UK.

[9] M A Humphreys, F Nicol, 1998, Understanding the Adaptive Approach to Thermal Comfort, ASHRAE Trans

[10] N H Wong, S S Khoo, 2003, Thermal Comfort in Classrooms in the Tropics. Energy and Buildings Journal, 35, 337-351.

[11] H Feriadi H, NH Wong, 2004, Thermal Comfort for Naturally Ventilated Houses in Indonesia, Energy and Building Journal, 36, 614-626.

[12] N Oseland, 1998, Adaptive Thermal Comfort Model, ASHRAE Trans

[13] GS Brager, R De Dear, 1997. Thermal Adaptation in the Built Environment: A Literature Review, Energy and Buildings Journal, 27, 83-96

'[14] Humphreys, M.A. 1976, Field Studies of Thermal Comfort Compared and Applied, Building Services Engineer Journal, 44, 5-27.

[15] Humphreys,M.A., 1978, Outdoor temperatures and Comfort indoors, Building Res. and Practice Journal, 6, 2.

[16] A Auliciems, 1981, Towards a psychological model of thermal perception, Int.J.Biometeor Journal, 25, 109-122.
[17] R De Dear, GS Brager, 2002, Thermal comfort in naturally ventilated buildings: revisions to ASHRAE Standard 55, Energy and Buildings Journal, 34, 549-561.

[18] Heerwagen, 2004, Passive and Active Environmental Controls, New York: McGraw-Hill .Inc

[19] C Huizenga, H Zhang, P Mattelaer, E Arens , 2005, Window Performance For Human Thermal Comfort, Final Report to the National Fenestration Rating Council, Berkeley, USA

[20] J Toftum, 2004, Air Movement - Good or Bad? Indoor Air Journal, 14, 40-45

[21] Architectural Institute of Japan, 2005, Architecture for a sustainable future, All about the holistic Approach in Japan, Japan, Institute for Building Environment and Energy Conservation

[22] DJ Harimi, SP Narayanan, CC Ming, Building versus Climate for Energy Consciousness, Proceedings of the 2nd SANREM Conference 2006, Malaysia

[23] B Givoni, 1994, Passive and Low Energy Cooling of Building, New York, Van Nostrand Reinfold

[24] R Aynsley, L Gulson, 1999, Microclimate and Urban Planning in the Humid Tropics, 27th National Congress, James cook University, Australia

[25] F Proges, 1995, HVAC Engineer's Handbook. , England, Progres, 1995

[26] M A Humphreys, 1970. A simple Theoretical Derivation of Thermal Comfort Conditions, Journal of the Institute of Heating and Ventilating Engineers, 33, 95-98

[27] A J Tinker, S H Ibrahim, 2003, Low-Income Housing in Developing Countries: An Evaluation of Thermal Comfort, Proceedings of the Second International Conference on Construction Technology, Kota Kinabalu, Sabah, Malaysia, 40-52.

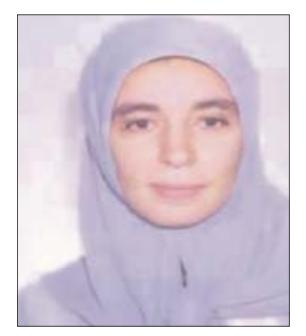

Ms. Harimi Djamila is a Research Scholar at the School of Engineering \& Information Technology, University Malaysia Sabah, Malaysia. She acquired her Engineering Degree from Algeria and a post-graduate degree in Civil Engineering from University Malaysia Sabah. Her field of research is Passive Design, Thermal Comfort and Energy Efficiency. 